4. Українське суспільство на порозі третього тисячоліття. - К., 1999.

5. Марчук Е. Украина: новая парадигма прогресса. - К. : Аваллон, 2001.

6. Стереотипы и динамика мышления. - Минск, 1993.

7. Князева Е.Н. Трансдисциплинарные комплексы знаний: синергетическая мудрость и образование // Полигнозис. - 2001. - № 2.

8. Сингх Раджа Рой. Образование в условиях меняющегося мира // Перспективы. Вопросы образования. - 1993. - № 1.

9. Тоффлер Э. Шок будущего. - М. : ООО «Издательство АСТ», 2002.

DOI https://doi.org/10.30525/978-9934-26-173-2-5

\title{
SOCIAL TRANSITIVITY AS A FACTOR IN THE FORMATION OF THE VALUE STRUCTURE OF A PERSON IN THE PROCESS OF STUDYING AT A UNIVERSITY
}

\author{
Kaimanova Y. V. \\ Senior Lecturer of Psychological Department \\ Donetsk Institute Private Joint-Stock Company "Higher Educational \\ Institution" Interregional Academy of Human Resources Management \\ Kramatorsk, Ukraine \\ Riabokon N. S. \\ Senior Lecturer of Psychological Department \\ Donetsk Institute Private Joint-Stock Company "Higher Educational \\ Institution" Interregional Academy of Human Resources Management \\ Kramatorsk, Ukraine
}

The formation of a normative-value structure is traditionally regarded as one of the most important results of the socialization of an individual. Values seem to be an obvious manifestation of the intersection of the regulation of human actions and the environment. Values are formed under the influence of social experience assimilated by a person and they are manifested in the goals, ideas, convictions of the personality itself and set the vector for the development of the personality and the content side of its activity, determining the general approach of a person to himself, to other people and to the world as a whole, giving meaning and direction to his behavior and activities. The general concept of «value» characterizes such concepts as social and personal 
values, value ideas, value orientations, value attitudes, value experiences, value consciousness [3].

The formed system of values structures and puts in order the picture of the world for the individual. An important feature of social values is that, by virtue of their universal acceptance, they are perceived by members of society as something which is taken for granted. A stable system of values which is widespread in society forms a system of social norms. An objective social norm is a characteristic of existing phenomena or processes. Social norms put in order various types of social relations, forming a certain hierarchy of norms. The mass social practice of people is generalized in a social norm.

A separate problem is the relationship between the parameters of social perceptions and the values of an individual. The measure and degree of such coincidences depend on many reasons - the social factors will belong to the external reasons, and the individual psychological characteristics will make up internal ones. "Value relations are a condition for the interiorization of social values by an individual, and the formation of value consciousness, different values have varying degrees of commonality and some are the concretization of others» [1].

Values are constructive formations that perform the function of categorizing and constructing a picture of the world and organizing human behavior within the framework of a consciously chosen direction of life. In their development, values move from formations of an exclusively cognitive nature to constructs (containing an emotional and regulatory component) due to the subject's awareness and understanding of his own behavior (in part, the divergence of his actions and value concepts). As a mechanism for the formation of individual values, M. A. Khachatryan proposes a value selection and builds a model of a possible variant of the process of this selection [4].

The formation of value orientations is a process accompanied by value experiences, by some kind of evaluative activity, in the result of which a person realizes the social reality and forms his own special value-based attitude to it [3].

D. A. Leontiev identified four types of relationships between personal and social values, according to the degree of their concurrence:

conflict development (maximum coincidence of the core of values and the periphery of the individual value structure, common in a given society);

variable development (some, insignificant concurrence of the nuclei of individual and social value structures and the divergence of their peripheries);

marginal development (some, insignificant concurrence of the periphery of individual and social value structures and a complete mismatch of value cores); 
deviant development (some, insignificant concurrence of the periphery of individual and social value structures and a complete mismatch of value cores). Each of these types of correlation of personal and social values is associated with various options for socialization of the individual [2].

The main characteristics of the social situation that determine a specific period in the life of society are manifested unevenly. For us, the most important characteristic of modern society is its transitivity. It manifests itself in the lengthening of the period of childhood, increasing of the gap between generations, accelerating of the dynamics of institutions of socialization. The lengthening of childhood is associated primarily with the general complication of life. The forms of social interaction are changing. They become much more complex, mediated, and varied.

These changes determine not only the need for a longer period of childhood, but also cause a widening gap between generations. The speed of life change devalues much of a person's social experience extremely quickly. The value structure of this experience is changing. The ways of obtaining it, readiness for changes, and taking into account the situations of a high degree of uncertainty are beginning to acquire a great value.

These characteristics of the social context can be included in a more general characteristic of the modern society, namely social transitivity.

Thus, in the conditions of a transitive society, the process of socialization acquires a fundamental inconsistency. On the one hand, socialization is the transmission of an established, entrenched social experience, on the other hand, in the modern life situation the experience of generations is getting shaped in a completely new way. A special place is occupied by the problem of the formation of values precisely in the youthful period of a personality development.

\section{References:}

1. Zhukov Y. M. Values as determinants of decision-making: a sociopsychological approach to the problem. Psychological problems of the regulation of social behavior. M.: Science, 2010. P. 56-59.

2. Leontiev D. A. On the motivational nature of personal values. Vestnik Mosk. state university, 2009. № 4. P. 24-27.

3. Tikhomandritskaya O. A. Values and self-attitude at the stage of youthful socialization: dis. ... Cand. psychol. sciences / Moscow state University, Moscow, 2000.

4. Khachatryan M. A. To the problem of the development of the subject's value system: a constructivist perspective. Psychological research, 2015. 8(41). 7. P. 51-55. 